\title{
DETERMINANTS OF THE PRESENCE OF CSR COMMITTEES WITHIN EUROPEAN BOARDS OF DIRECTORS
}

\author{
Edina Eberhardt-Toth, Jérôme Caby, Corinne Gendron et Lovasoa Ramboarisata
}

ESKA | «Revue de l’organisation responsable »

2019/1 Vol. 14 | pages 33 à 49

ISSN 1951-0187

ISBN 9782747228916

Article disponible en ligne à l'adresse :

https://www.cairn.info/revue-de-l-organisation-responsable-2019-1-page-33.htm

Distribution électronique Cairn.info pour ESKA.

(C) ESKA. Tous droits réservés pour tous pays.

La reproduction ou représentation de cet article, notamment par photocopie, n'est autorisée que dans les limites des conditions générales d'utilisation du site ou, le cas échéant, des conditions générales de la licence souscrite par votre établissement. Toute autre reproduction ou représentation, en tout ou partie, sous quelque forme et de quelque manière que ce soit, est interdite sauf accord préalable et écrit de l'éditeur, en dehors des cas prévus par la législation en vigueur en France. Il est précisé que son stockage dans une base de données est également interdit. 


\title{
DETERMINANTS \\ OF THE PRESENCE \\ OF CSR COMMITTEES \\ WITHIN EUROPEAN BOARDS \\ OF DIRECTORS
}

\section{Edina EBERHARDT-TOTH}

CEREFIGE-ICN Business School

Address: ICN Business School, 86 Rue du Sergent Blandan, CS 70148, 54003 Nancy Cedex, France

Email: edina.eberhardt-toth@icn-artem.com

Corresponding Author

\section{Jérôme CABY}

IAE Paris, Université Paris 1 Panthéon-Sorbonne (Sorbonne Business School)

Address: IAE de Paris, 8 bis rue de la Croix Jarry, 75013 Paris, France

Email: caby.iae@univ-paris1.fr

\section{Corinne GENDRON}

UQAM, Université du Québec à Montréal

CEREFIGE-ICN Business School, Affiliated Professor of Research

Address: UQAM, Case postale 8888, succursale Centre-ville, Montréal (Québec) H3C 3P8, Canada

Email: gendron.corinne@uqam.ca

\section{Lovasoa RAMBOARISATA}

UQAM, Université du Québec à Montréal

Address: UQAM, Case postale 8888, succursale Centre-ville, Montréal (Québec) H3C 3P8, Canada

Email: ramboarisata.lovasoa@uqam.ca

\begin{abstract}
In this paper, we analyze an under-examined strategic structure: the corporate social responsibility (CSR) committee within the board of directors. We conduct univariate analysis and binary logistic regressions on the determinants of the presence of a CSR committee within the board of 427 companies in non-financial industries included in the STOXX Europe 600 Index for the years 20062011. Besides firm size and industry type, our findings suggest that a CSR committee is more likely to be present in companies that operate in a common law jurisdiction and when the CEO is also chair of the board. Combining those results with insights from the variety of capitalism, strategic choice, and resource-based perspectives, our paper contributes to the non-stabilized literature on the link between CSR and governance by nuancing prior hypotheses and findings about the determinants of the presence of a CSR committee within a board of directors.
\end{abstract}

Keywords: Corporate governance, Board effectiveness, CSR committee, Corporate social performance, Corporate social responsibility. 


\section{RÉSUMÉ}

Cet article porte sur une structure stratégique jusqu'à présent peu étudiée : le comité de responsabilité sociale de l'entreprise (RSE) au sein du conseil d'administration. Une analyse univariée ainsi que des régressions logistiques binaires sont réalisées sur les déterminants de la présence d'un comité RSE au sein du conseil d'administration de 427 entreprises de secteurs non financiers du STOXX Europe 600 Index pour les années 2006 à 2011. Outre la taille de l'entreprise et le secteur d'appartenance, nos résultats suggèrent que les comités RSE sont davantage présents dans les entreprises qui opèrent dans les juridictions de common law et lorsque le directeur général agit également comme président du conseil d'administration (PDG). Articulant ces résultats avec les éclairages des approches de la variété du capitalisme, des choix stratégiques et de la stratégie par les ressources, notre article contribue à la littérature encore non stabilisée sur la relation entre la RSE et la gouvernance en nuançant les hypothèses et conclusions antérieures sur les déterminants de la présence d'un comité RSE au sein du conseil d'administration.

Mots-clés : Gouvernance d'entreprise, Conseil d'administration, Comité RSE, Performance sociale de l'entreprise, Responsabilité sociale de l'entreprise.

\section{LIST OF ABBREVIATIONS}

BOD: Board of directors

CEO: Chief executive officer

CSR: Corporate social responsibility

DJSI: Dow Jones sustainability indexes

ESG: Environmental, social, and governance

ICB: Industry classification benchmark

SAM: Sustainable Asset Management, Zurich

\section{INTRODUCTION}

Although many studies have explored the links between corporate social responsibility (CSR) and corporate governance, only a very few have examined the structures that are established within companies in order to determine how directors incorporate CSR into their decision-making processes. However, as noted by Elkington (2006), public pressure has pushed companies to place the triple bottom line agendum within the responsibility of board members. Elkington called for research into how economic, social, and environmental values, born by the triple-bottom-line concept of CSR (Elkington, 1998), can be created through better corporate governance systems.

Studies on corporate governance such as those of Nelson, Zollinger, \& Singh (2001), Tonello (2010), and Tonello et al. (2011) stress the increasing role of the board of directors (BOD) in the strategic management of CSR. Moreover, board committees have a strategic role to play in achieving corporate legitimacy, accountability, transparency, and strategy formulation (Harrison, 1987; Cartwright \& Craig, 2006; Brauer \& Schmidt, 2008;
Brennan \& Solomon, 2008; Horner, 2011; Perrault \& McHugh, 2015; Barroso-Castro et al., 2017; Fuentel et al., 2017). Hence, we argue that it is relevant to understand the positioning of the CSR agenda at a strategic level of decision-making. More specifically, this paper examines which factors determine the presence of CSR committees within the BOD. A CSR committee within the BOD is a specific board sub-committee that handles CSR topics such as ethics, environment, community engagement or health and safety (ISO 26000). As those committees are not specifically regulated, there is no established definition of a CSR committee. Based on the ISO 26000 definition of social responsibility and Environmental, Social and Governance (ESG) criteria of responsible investment principles (UN PRI, 2016), we included as CSR committees all formalized sub-committees, separated within the board, entitled as follow: ethics committee, sustainable development committee, environment, health, and safety committee or any combination of them. These committees take care of regulated as well as non-regulated CSR issues, whether they concern the environment, ethics or social questions.

The presence of this type of committee in companies within non-financial industries in the STOXX Europe 600 Index doubled, from $9.03 \%$ to $18.27 \%$, between 2006 and 2011. The yearly increases are shown in Table 1. According to Kinderman (2013), the CSR policies of the European Union changed from being social-liberal to neo-liberal in 2006 and returned to being social-liberal in 2011. Therefore, the period between 2006 and 2011 was a decisive period in European CSR history, when there was a struggle to achieve legitimacy for CSR. Kinderman (2013) argues that the financial crisis re-empowered CSR standard-setters, as could be seen with the proposition of a Green New Deal (UNEP, 2011). The growing 
Table 1: Presence of CSR Committees within Boards of companies within non-financial industries in the STOXX Europe 600 Index between 2006 and 2011

\begin{tabular}{|c|c|c|c|c|}
\hline \multirow{2}{*}{ Period } & \multicolumn{2}{|c|}{ Board CSR Committee } & \multirow{2}{*}{$\begin{array}{c}\text { Total } \\
\text { number of } \\
\text { companies }\end{array}$} & Percent \\
\cline { 2 - 5 } & Not Present & Present & 421 & $9.03 \%$ \\
\hline 2006 & 383 & 38 & 424 & $10.38 \%$ \\
\hline 2007 & 380 & 44 & 426 & $11.50 \%$ \\
\hline 2008 & 377 & 49 & 427 & $13.58 \%$ \\
\hline 2009 & 369 & 58 & 427 & $16.16 \%$ \\
\hline 2010 & 358 & 69 & 427 & $18.27 \%$ \\
\hline 2011 & 349 & 78 & 2552 & $13.17 \%$ \\
\hline Total & 2216 & 336 & & \\
\hline
\end{tabular}

number of investors' interest in the normalisation of firms' ESG performance (for example, the creation of the UN principles for responsible investment in 2006) can also be assumed as an explanation. Moreover, the ISO 26000 standard adopted at the end of 2010 was progressively disseminated to the business committee as of 2011, opening a new era for social responsibility engagement in the business community.

Our goal is to understand the conditions in which companies have a CSR committee within the BOD. It is difficult for stakeholders of a company to measure CSR. Therefore, when a CSR committee is established within a BOD, this can be interpreted as a signal from board directors to the stakeholders that CSR issues are being considered at a strategic level in the company. Porter \& Kramer (2006) also argue that CSR should be integrated into organizational processes. Moreover, stakeholder theory implies the creation of governance structures (Donaldson \& Preston, 1995) and in this perspective, Luoma \& Goodstein (1999) stress the need for structures, especially within the BOD, that can respond to stakeholder concerns.

Earlier studies have addressed attributes of the BOD - such as diversity, independence, directors' ethical training, financial and extra-financial expertise - that determine a better social performance and more CSR transparency (Harjoto \& Jo, 2011; Jizi et al., 2014; Rao and Tilt, 2016; Shaukat et al., 2016; Fuentel et al., 2017; McGuinness et al., 2017; Galbreath, 2018). Our study focuses on an overlooked board attribute, the specialisation of function through the presence of a CSR committee. It assesses whether this need for a CSR-specialized governance structure is met by companies. It does so by analysing when CSR committees are present within BODs. The variety and number of board sub-committees has increased since the 1960s, and CSR committees first started to appear in the 1970s (Harrison, 1987). However, very few studies of these CSR committees have been carried out. Thus, the research presented here is essentially exploratory and will hopefully lead to more extensive investigations.
Our starting point is that not all responsible companies choose to create a distinct CSR committee within the $\mathrm{BOD}$; some of them rather consider that CSR is an integral part of every strategic formulation for each board director. Then, the question raised is to understand when a CSR committee is seen as a necessary tool for integration of CSR into the strategy of the company. Numerous factors can explain this choice, starting from the effectiveness in board processes for CSR, the level of corporate social performance, or a high contextual sensitivity to CSR. To understand the presence of a CSR committee within the BOD, first we develop a theoretical framework and hypotheses. Following this, we present the data, methods and empirical results. Then we discuss the theoretical and practical implications of the findings, the limitations of the study and potential avenues for further research.

\section{DEVELOPMENT OF HYPOTHESES}

Many actors put pressure on companies to achieve social change (Aguilera, Rupp, Williams, \& Ganapathi, 2007). Here, we build on Golden \& Zajac (2001) to determine the variables that could influence the presence of a CSR committee within a BOD aimed at achieving strategic changes for CSR. The first factors might lie in the board itself, as Golden \& Zajac (2001) argue that boards will influence strategy if they have the power and inclination to achieve strategic change. Menon $\&$ Williams (1994) and Fiss \& Zajac (2004) argue that a board sub-committee may be created to improve the company's image, without the board being really engaged with the issues the committee is supposed to address. Recent publications have however provided empirical results that contradict this view. Danvila del Valle, Diez Esteban, \& Lopez de Foronda (2013) stress the importance of the presence of a CSR committee within a BOD to CSR performance, especially when the CSR committee is composed of independent directors. Moreover, Eccles, Ioannou, \& Serafeim (2011) provide 
Figure 1: Determinants of the Presence of a CSR Committee within the Board of Directors

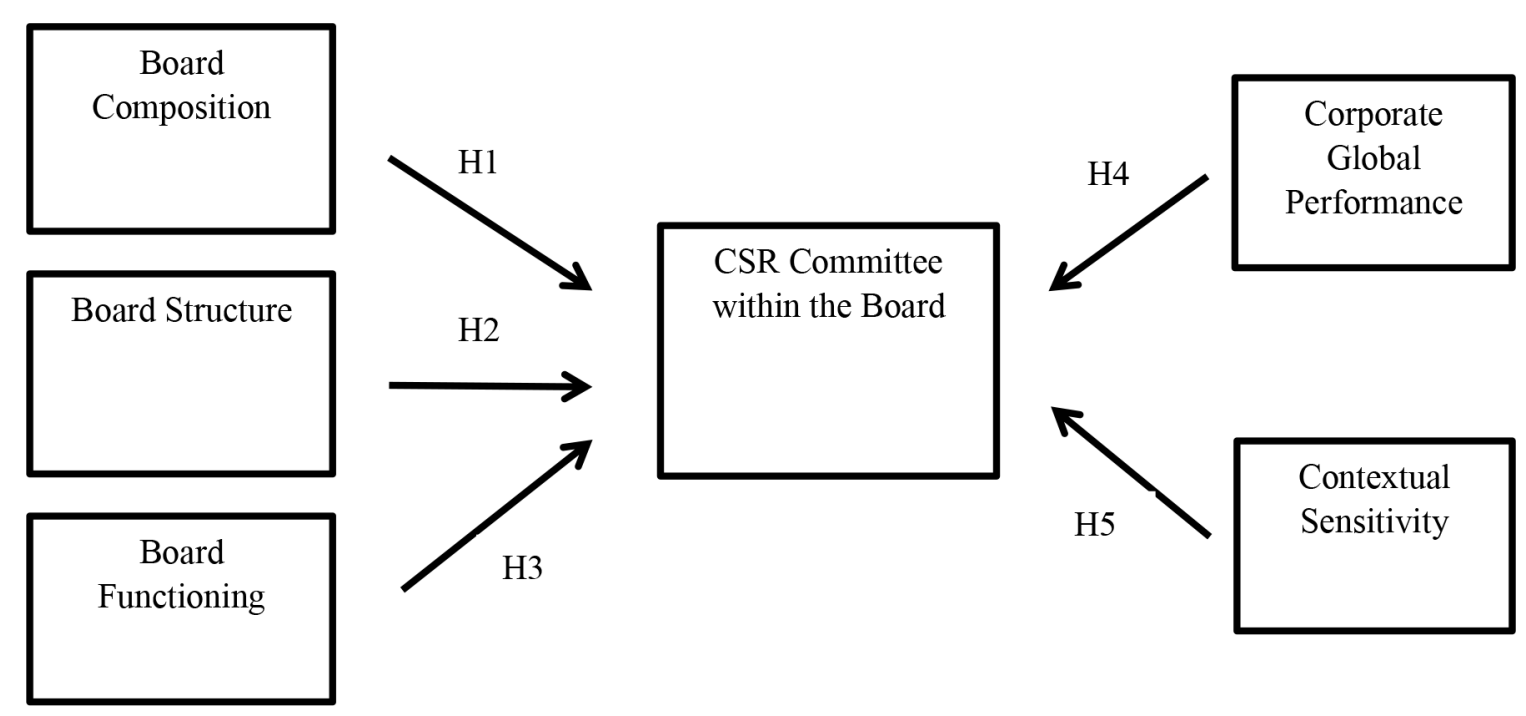

empirical evidence that companies with a strong sustainability culture tend to create a CSR committee within their BOD. Also, the existence of a CSR committee within a BOD has been found to be positively associated with social involvement to the community (Mallin \& Michelon, 2011). Therefore, when developing our hypotheses, we considered that the presence of a CSR committee within a BOD signals that CSR is indeed already present in the company's strategic processes. Other factors, relative to the firm itself or external, can explain the presence of a CSR committee. As we will explain later, the size of the firm, the nature of its activities but also the regulatory environment can also have an impact.

Consequently, in this study, we first test the distinctive features of the BOD that might explain the presence of a CSR committee within a BOD. We build upon the Forbes \& Milliken (1999) model about the effectiveness of board processes to formulate hypotheses about the composition, structure and functioning of the board (hypotheses $\mathrm{H} 1$ to $\mathrm{H} 3$, respectively). We also proposed hypotheses related to the specificities of the firm and the context in which it operates (hypotheses $\mathrm{H} 4$ and $\mathrm{H} 5$, respectively).

Therefore, the model we propose to test the determinants of the presence of a CSR committee within a BOD is based on 5 factors summarized in Figure 1.

\section{A. A cognitive perspective of group decision- making to understand board dynamics}

Elkington (2006: 524) states that "The better the system of corporate governance, the greater the chance that we can build towards genuinely sustainable capitalism”. Moreover, Beltratti (2005) argues that good governance and CSR are complementary and that companies that adopt both are more respected and have higher market value than those that do not. Also, Ntim \& Soobaroyen
(2013) found that better governed companies are more likely to have stronger CSR practices.

Towards the end of the 1990s, studies of BODs and strategies have shifted from a normative to a cognitive approach (Pugliese et al., 2009). Rindova (1999) identifies the cognitive contributions of board directors, especially in relation to strategic decision-making, and states that they are characterized by a high level of uncertainty and complexity. The three cognitive tasks - scanning, interpreting, and choosing - as described by Rindova (1999), are particularly useful in managing the diverse goals of different stakeholders. Porter and Kramer (2006) propose that companies should map the social impacts of their value chain and prioritize them to generate the greatest shared value. Board directors can then use the three cognitive tasks identified by Rindova (1999) to achieve this aim. Cognitive and disciplinary approaches to corporate governance are complementary and evolve over time (Aoki, 2001). Knowledge of innovation processes is progressively acquired by a company, and cognitive approaches are required more at the beginning of the organizational learning process, whereas disciplinary approaches are more required in the later stages, when company processes tend to change less. In light of the foregoing, we adopted a cognitive approach to examine companies that innovate in their internal processes by creating a CSR committee within a BOD. In the development of our hypotheses, we build on the Forbes \& Milliken (1999) model about the effectiveness of board processes by identifying different variables about the composition of the board, its structure and its functioning that altogether determine the cognitive capacity and power of the board. Therefore, if many of these attributes on which the cognitive capacity and the power of the BOD depend are already present, we can also suppose that it is no longer useful for the company to create a dedicated committee, especially in the context of implicit CSR and scarcity of resources. 


\section{B. Hypotheses on the composition and structure of the board}

One of the most important features of efficient boards is their capacity to foresee a variety of issues and to bring distinct logic in the analysis of the business environment of the firm and the evaluation of its strategy. This feature is conceptualised by Forbes \& Milliken as cognitive conflict, and defined as "task-oriented differences in judgment among group members". They explain that "the existence of cognitive conflict on the board can serve to remind management (...) of the importance of considering shareholder interests in the formulation of strategy even beyond the boardroom" (1999: 494). Independent and women directors can increase the variety of points of view, as suggested by the concept of cognitive conflict. This may also be true of separating the functions of $\mathrm{CEO}$ and chairperson (non-duality of responsibilities). To these variables, we added the average age of the board, given that younger people tend to be more sensitive to CSR issues. We develop hereafter our arguments concerning each variable.

According to Wang \& Dewhirst (1992), independent board directors have different stakeholder orientations than do non-independent directors. Rindova (1999) argues that board directors are general experts in problem-solving and that this can counterbalance their lack of specific knowledge about the firm itself, which is the case when they are independent board directors. More specifically, Danvila del Valle et al. (2013) found that the presence of a higher proportion of independent board directors was positively related to CSR performance. Harjoto \& Jo (2011) concluded from their study of firms within Russell 2000, S\&500 and Domini 400 indices during the 1993-2004 period that board independence is among the companies' board attributes that are positively associated with the choice to engage with CSR. Shaukat et al. (2016) developed a theoretical model that made explicit the links between a firm's CSR-related board attributes, its board CSR strategy, and its environmental and social performance, then tested it using a structural equation modeling approach. They found that board's independence and gender diversity determine more proactive and comprehensive CSR strategy and higher environmental and social performance. Other studies (Post, Rahman, \& Rubow, 2011; Zhang, Zhu, \& Ding, 2013; Mallin \& Michelon, 2011; Webb, 2004) demonstrated that a greater presence of independent board directors is associated with a stronger environmental performance. When women are present on the BOD, there is likely to be more diversity and a greater likelihood of cognitive conflicts between board directors (Muller-Kahle \& Lewellyn, 2011). Also, according to Boulouta (2013) and Qi (2018), more women on the BOD leads to stronger corporate social performance, which, it is argued, is especially caused by the generally more empathic and caring nature of women in contrast to men. The presence of a higher proportion of female board directors was found to be related to higher firms' CSR engagement and CSR ratings by Bear et al. (2010), Zhang et al. (2013), Mallin \& Michelon (2011), Webb (2004), Rao et al. (2016), Shaukat et al. (2016), Fuentel et al. (2017, McGuinness et al. (2017), and Galbreath (2018). In addition, Post et al. (2011) found that boards with at least three women directors were associated with stronger corporate environmental performance, while Schwartz-Ziv (2013) found that boards with increased gender-balance achieve stronger financial performance and are more active.

CEO duality means that the CEO is also the chairman of the board, and this leads to less cognitive conflict than CEO non-duality, that is, when the CEO and the chairman of the board are not one and the same person. Wang \& Dewhirst (1992) found that CEO board directors and non-CEO board directors view stakeholders differently. Socially responsible companies are less likely than non-socially responsible companies to have CEO duality (Webb, 2004). CEO duality has been also found to be negatively associated with corporate social performance by Mallin \& Michelon (2011). Finally, the average age of the board seems an appropriate variable to be tested since younger individuals demonstrate more knowledge of environmental issues than do older individuals (Diamantopoulos, Schlegelmilch, Sinkovics, \& Bohlen, 2003). Gendron (2012) also showed that younger high managers are more aware of the environmental issues than their older colleagues. Moreover, companies that have a lower average age of top managers are more likely to undergo strategic change (Wiersema \& Bantel, 1992). Wu, He, Duan, \& O’Regan (2012: 244) state that "the question is not whether companies should make strategic change toward sustainability, but how quickly and how well companies can make such change and find new opportunities from the market environment".

In light of the above, we propose the following hypotheses:

Hypothesis 1a: A CSR committee within the BOD is more likely in companies with younger board directors. Hypothesis 1b: A CSR committee within the BOD is more likely in companies with a higher proportion of independent board directors.

Hypothesis 2a: A CSR committee within the BOD is more likely in companies in which the $C E O$ is not also the chair of the board.

Hypothesis 2b: A CSR committee within the BOD is more likely in companies with a higher proportion of women on the board.

\section{Hypotheses on board functioning}

Forbes \& Milliken (1999) first define the functioning of the board through its efforts, measured by the time allocated to its different tasks. We considered the number of board meetings and board attendance as proxies for board functioning. Raghunandan \& Rama (2007), in 
their study of the audit committee within the BOD, used the number of meetings of a committee as a quantitative, publicly available measure of the diligence of the committee. The authors stress that the Securities and Exchange Commission also recommends having several meetings to foster the circulation of information and that previous research has demonstrated that a higher number of meetings improves the quality of financial reporting. Cornforth (2001) argues that board meetings and board attendance, in particular, are suitable variables for measuring board effectiveness.

In light of the above, we propose the following hypotheses on board effort:

Hypothesis 3a: A CSR committee within the BOD is more likely in companies that have more board meetings. Hypothesis 3b: A CSR committee within the BOD is more likely in companies with higher board attendance.

\section{Hypotheses on corporate global performance and contextual sensitivity}

\section{a. Corporate global performance variables}

Hung (2011) argues that, from a stakeholder perspective, directors have a social responsibility and states that their "direction-setting role" is related to corporate performance. Corporate global performance includes the social, environmental, and economic performance of a company. The role of an effective CSR committee within a BOD is to foster CSR in strategic decisions; therefore, we suggest that corporate global performance variables should be positively associated with the presence of this sub-committee. We considered three corporate global performance variables: the first two concern more specifically social performance: belonging to a CSR index, and ESG disclosure; the third concerns financial performance, and is also linked to social performance. Belonging to a CSR index signifies that a company has higher social, environmental, and economic ratings than other companies. To achieve this requires the strong involvement of the board in addressing CSR issues. Danvila del Valle and al. (2013) found that the presence of a CSR committee within a BOD is associated with inclusion in a CSR index.

The aim of ESG disclosure is to promote sustainability practices among companies, and disclosure can be on a voluntary basis or enforced by regulation. For example, the Nouvelles Régulations Economiques law in France has obliged listed companies to undertake social and environmental reporting since 2001, and the BOD is legally responsible for the report. Large companies that are not listed have also been required to undertake CSR reporting in France since 2012. We suggest that, particularly because of such laws, board directors will have an increased knowledge of ESG disclosure and that this can make the creation of a CSR committee within a BOD more likely, particularly when CSR reporting is required. Ioannou \& Serafeim (2011) found that mandatory ESG disclosure positively influences social and environmental performance. Also, according to empirical evidence presented by Mallin, Michelon, \& Raggi (2013), social and environmental disclosure is likely to be positively linked to stakeholder orientation of corporate governance.

The link between financial performance and CSR engagement has been largely studied (see e.g., Orlitzky, Schmidt, \& Rynes, 2003; Waddock \& Graves, 1997). Notably, Allouche $\&$ Laroche (2005) in a meta-analysis found 49 positive associations, 6 negative, 17 mixed and 21 non-significant. Campbell (2006: 929) states that "firms whose financial performance is strong are more likely to engage in socially responsible corporate behavior than firms whose financial performance is weak". Financial performance can thus also contribute to the presence of a CSR committee as a means to enhance CSR performance. In summary, corporate global performance as assessed by the presence in a CSR index, ESG disclosure practices and financial performance should influence positively the presence of a CSR committee. This leads to the following three hypotheses:

Hypothesis 4a: A CSR committee within the BOD is more likely in companies belonging to a CSR index. Hypothesis 4b: A CSR committee within the BOD is more likely in companies with stronger ESG disclosure. Hypothesis 4c: A CSR committee within the BOD is more likely in companies with stronger financial performance.

\section{b. Contextual sensitivity variables}

Contextual sensitivity can be described as the sensitivity of companies to CSR issues due to specific characteristics of the firm and its environment. Pugliese et al. (2009) suggest that it is important to study factors specific to the context of each company when assessing the contribution of the BOD to strategy. Therefore, we examined how the presence of a CSR committee within a BOD is related to the following contextual sensitivity variables: firm size, jurisdiction and industry type.

Davis, Whitman, \& Zald (2006) suggest that the role of large multinational companies is important in the diffusion of best social practices amongst other companies through suppliers and other contractors. Larger firms, given their high visibility, high level of access to resources, and large operational scale, are more likely to participate in CSR (Udayasankar, 2008). Also, Artiach, Lee, Nelson, \& Walker (2010) found that larger companies have better corporate social performance.

In our study, to identify how legal regulations can influence the presence of a CSR committee within a $\mathrm{BOD}$, we compared companies with headquarters in European countries that apply common law to those applying civil law. La Porta, Lopez-de-Silanes, Shleifer, \& Vishny (1998) distinguish between several legal systems. 
More recently, Cicon, Ferris, Kammel, \& Noronha (2012) reassessed these legal systems, based on their prevailing national corporate governance structures. However, they kept the taxonomy used in La Porta et al. (1998), which was broadly, common law and civil law, and we use the same taxonomy in this study. Hence, we group French, German and Scandinavian countries under "civil law countries" while we assign the United Kingdom and the Republic of Ireland to "common law countries". La Porta et al. (2008: 326) explain the fundamental divergence between these two legal traditions in terms of the "policy implementing focus of civil law versus the market-supporting focus of common law". Matten \& Moon (2008) argue that CSR is an explicit corporate element in liberal market economies, whereas it is an implicit corporate element in coordinated market economies. Therefore, a need to be explicit about CSR issues may predict the need for companies to establish a CSR committee within their BOD when operating in common law countries. One of the determinants of the impact of industry on social and environmental responsibility, according to Hoepner, Yu, \& Ferguson (2010), is their potential for social and environmental damage. The basic materials category within the industry classification benchmark (ICB) owned by the Financial Times Stock Exchange (FTSE, 2012) contains the chemicals, forestry and paper, industrial metals, and mining industries, and these are some of the most detrimental industries in terms of ecological impact and effects on human health. Stakeholders therefore expect BODs in these industries to pay a great deal of attention to social and environmental issues.

In light of the above, we propose the following hypotheses on contextual sensitivity:

Hypothesis 5a: A CSR committee within the BOD is more likely in larger companies than in smaller companies.

Hypothesis 5b: A CSR committee within the BOD is more likely in companies that have headquarters in common law countries.

Hypothesis 5c: A CSR committee within the BOD is more likely in companies in the basic materials industry. Next, we describe the data sample, measures for the variables, and descriptive statistics together with our justification for the use of binary logistic regression in the subsequent analysis.

\section{DATA AND METHODS}

\section{A. Sample}

We performed a firm-level analysis of 427 companies within non-financial industries per year that were in the STOXX Europe 600 Index of the period 2006-2011 (six years), just before the ISO 26000 standard was disseminated to the business community. Our sample consisted of an unbalanced panel with 2562 firm-year observations. We used a European sample following Cicon et al. (2012). They argue that because the largest European companies are active on the global scale, this allows an assessment of the impact of different legal systems on these companies.

\section{B. Measures of the variables}

Annual company reports provide only a certain amount of information on the social and environmental performance of companies because these reports are currently seen primarily as a communication tool (Caron \& Gendron, 2012). Therefore, we used the Bloomberg database to access information on the companies in our sample because it is widely recognized as a good source by the business community due to the reliability of its data. Table 2 gives the measures and sources of the dependent variable and independent variables.

We also developed a collaborative relationship with the Sustainable Asset Management (SAM) organization, which is based in Zurich, Switzerland. This organization is one of the market leaders in assessing and integrating financial and non-financial data, and its index team has determined which companies should be listed in the Dow Jones Sustainability Indices each year since 1999. Sustainable Asset Management uses a best-in-class industry-specific approach to assess information provided directly by companies through an online questionnaire and companies also provide documentation to support their answers. The corporate sustainability assessment used by SAM has a question level, a criterion level, and a social/environmental/economic dimension level. Each level is weighted (as a percentage) to allow a total sustainability score to be calculated, as described in their publicly available methodological guidelines (SAM, 2012). Sustainable Asset Management invites the world's largest 2500 publicly traded companies to participate in this corporate sustainability assessment. We used, in our investigation, the Dow Jones Sustainability Europe Index membership list provided by SAM as their assessment of corporate social performance is based on the same 600 largest European companies as our sample data. Several research studies have been conducted using the Dow Jones Sustainability Indices, including Artiach $e t$ al. (2010), Eccles, et al. (2011) and Danvila del Valle, et al. (2013). SAM became RobecoSAM in 2013.

\section{Descriptive statistics}

The descriptive statistics for our sample, with the number of observations, the minima, maxima, means, and standard deviations, are shown in Table 3. In addition, the table includes information on the type of law applied in the countries in which the companies in the sample are established and on the industries to which the companies are assigned by the Industry Classification Benchmark (ICB). 
Table 2: Measures of Variables

\begin{tabular}{|c|c|c|c|c|}
\hline Variable code & Variable name & $\begin{array}{l}\text { Type of } \\
\text { variable }\end{array}$ & Definition & Source \\
\hline BOARD AGE & $\begin{array}{l}\text { Age of board } \\
\text { directors }\end{array}$ & Continuous & Average age of the board directors & Bloomberg \\
\hline $\begin{array}{l}\text { BOARD } \\
\text { ATTENDANCE }\end{array}$ & $\begin{array}{l}\text { Board } \\
\text { attendance }\end{array}$ & Continuous & $\begin{array}{l}\text { Percentage of members in attendance at board } \\
\text { meetings }\end{array}$ & Bloomberg \\
\hline $\begin{array}{l}\text { BOARD } \\
\text { INDEPENDENCE }\end{array}$ & $\begin{array}{l}\text { Independent } \\
\text { board directors }\end{array}$ & Continuous & Percentage of independent board directors & Bloomberg \\
\hline $\begin{array}{l}\text { BOARD } \\
\text { MEETINGS }\end{array}$ & $\begin{array}{l}\text { Board } \\
\text { meetings }\end{array}$ & Continuous & Number of board meetings per year & Bloomberg \\
\hline BOARD SIZE & Board size & Continuous & $\begin{array}{l}\text { Number of full-time directors on the company's } \\
\text { board. Where the company has a supervisory } \\
\text { board and a management board, this is the } \\
\text { number of directors on the supervisory board. }\end{array}$ & Bloomberg \\
\hline BOARD WOMEN & $\begin{array}{l}\text { Female board } \\
\text { directors }\end{array}$ & Continuous & Percentage of female board directors & Bloomberg \\
\hline CEO DUALITY & $\begin{array}{l}\text { Chief Executive } \\
\text { Officer (CEO) } \\
\text { duality }\end{array}$ & Binary & $\begin{array}{l}1=\text { CEO is also chairman of the board of } \\
\text { directors (BOD) } \\
0=\text { CEO is not chairman of the BOD }\end{array}$ & Bloomberg \\
\hline ESG DISCLOSURE & $\begin{array}{l}\text { Environmental, } \\
\text { social and } \\
\text { governance } \\
\text { disclosure }\end{array}$ & Continuous & $\begin{array}{l}\text { Proprietary Bloomberg score based on the extent } \\
\text { of the company's environmental, social and } \\
\text { governance disclosure. The score ranges from } \\
0.1 \text { for companies that disclose a minimum } \\
\text { amount of data to } 100 \text { for those that disclose } \\
\text { every data point collected by Bloomberg. Each } \\
\text { data point is weighted in terms of importance. }\end{array}$ & Bloomberg \\
\hline $\begin{array}{l}\text { FINANCIAL } \\
\text { PERFORMANCE }\end{array}$ & $\begin{array}{l}\text { Corporate } \\
\text { financial } \\
\text { performance }\end{array}$ & Continuous & $\begin{array}{l}\text { Return on Equity }=(\mathrm{T} 12 \mathrm{Net} \text { Income Available for } \\
\text { Common Shareholders/Average Total Common } \\
\text { Equity }) \times 100\end{array}$ & Bloomberg \\
\hline FIRM SIZE & Firm size & Continuous & $\begin{array}{l}\text { Logarithm of the firm's total assets in the balance } \\
\text { sheet }\end{array}$ & Bloomberg \\
\hline $\begin{array}{l}\text { INDUSTRY BASIC } \\
\text { MATERIALS }\end{array}$ & $\begin{array}{l}\text { Firm } \\
\text { membership } \\
\text { of a basic } \\
\text { materials } \\
\text { industry }\end{array}$ & Binary & $\begin{array}{l}\text { Membership of the industry named Basic } \\
\text { Materials in the Industry Classification } \\
\text { Benchmark (ICB) classification }\end{array}$ & Bloomberg \\
\hline COMMON LAW & $\begin{array}{l}\text { Domiciled in } \\
\text { a common law } \\
\text { country }\end{array}$ & Binary & $\begin{array}{l}1 \text { = common law country } \\
0=\text { civil law country } \\
\text { based on taxonomy by La Porta, Lopez-de- } \\
\text { Silanes, Shleifer, \& Vishny (1998) }\end{array}$ & Bloomberg \\
\hline CSR COMMITTEE & $\begin{array}{l}\text { CSR committee } \\
\text { within the } \\
\text { BOD }\end{array}$ & Binary & $\begin{array}{l}1=\text { Presence of CSR committee within the BOD } \\
0=\text { Absence of CSR committee within the BOD }\end{array}$ & $\begin{array}{l}\text { Bloomberg and } \\
\text { annual reports }\end{array}$ \\
\hline CSR INDEX & $\begin{array}{l}\text { Belonging to } \\
\text { a Corporate } \\
\text { Social } \\
\text { Responsibility } \\
\text { (CSR) index }\end{array}$ & Binary & $\begin{array}{l}\text { Belonging to the Dow Jones Sustainability } \\
\text { Europe Index as defined by Sustainability Asset } \\
\text { Management (SAM) based in Zurich }\end{array}$ & SAM \\
\hline
\end{tabular}

\section{Binary logistic regressions}

We carried out a panel data regression analysis for years 2006-2011. Our dependent variable was binary and took a value of 1 when a CSR committee was present within the $\mathrm{BOD}$ and 0 otherwise. We used binary logistic regression analysis to predict the presence of a CSR committee using the variables defined above and the following model:

CSR COMMITTEE $=a+b_{1}$ BOARD AGE $+b_{2}$ CEO DUALITY $+b_{3}$ BOARD WOMEN $+b_{4}$ BOARD INDEPENDENCE + $\mathrm{b}_{5}$ BOARD MEETINGS + $\mathrm{b}_{6}$ 
Table 3: Descriptive Statistics

\begin{tabular}{|c|c|c|c|c|c|}
\hline Variable & $\begin{array}{c}\text { Number of } \\
\text { observations* }\end{array}$ & Minimum & Maximum & Mean & $\begin{array}{l}\text { Standard } \\
\text { deviation }\end{array}$ \\
\hline BOARD AGE & 1582 & 46.70 & 70.42 & 57.50 & 3.76 \\
\hline BOARD ATTENDANCE & 1585 & 50.00 & 100.00 & 93.42 & 6.02 \\
\hline BOARD INDEPENDENCE & 1942 & 10.00 & 100.00 & 58.56 & 19.45 \\
\hline BOARD MEETINGS & 2002 & 2.00 & 36.00 & 8.58 & 3.44 \\
\hline BOARD SIZE & 2270 & 4.00 & 25.00 & 11.21 & 3.80 \\
\hline BOARD WOMEN & 2227 & .00 & 83.33 & 11.78 & 11.01 \\
\hline CEO DUALITY & 2259 & 0 & 1 & .14 & .34 \\
\hline ESG DISCLOSURE & 2263 & .83 & 76.33 & 33.00 & 16.76 \\
\hline FINANCIAL PERFORMANCE & 2467 & -134.14 & 198.65 & 19.88 & 22.25 \\
\hline FIRM SIZE & 2546 & 1.51 & 5.43 & 3.82 & .63 \\
\hline CSR COMMITTEE & 2552 & 0 & 1 & .13 & .34 \\
\hline CSR INDEX & 2562 & 0 & 1 & .28 & .45 \\
\hline CIVIL FRENCH LAW & 2562 & 0 & 1 & .32 & .47 \\
\hline $\begin{array}{l}\text { CIVIL SCANDINAVIAN \& GERMAN } \\
\text { LAW }\end{array}$ & 2562 & 0 & 1 & .36 & .48 \\
\hline COMMON LAW & 2562 & 0 & 1 & .33 & .47 \\
\hline INDUSTRY BASIC MATERIALS & 2562 & 0 & 1 & .12 & .32 \\
\hline INDUSTRY CONSUMER GOODS & 2562 & 0 & 1 & .15 & .36 \\
\hline INDUSTRY CONSUMER SERVICES & 2562 & 0 & 1 & .16 & .36 \\
\hline INDUSTRY HEALTHCARE & 2562 & 0 & 1 & .07 & .26 \\
\hline INDUSTRY INDUSTRIALS & 2562 & 0 & 1 & .27 & .44 \\
\hline INDUSTRY OIL AND GAS & 2562 & 0 & 1 & .07 & .26 \\
\hline INDUSTRY TECHNOLOGY & 2562 & 0 & 1 & .05 & .22 \\
\hline INDUSTRY TELECOM & 2562 & 0 & 1 & .04 & .21 \\
\hline INDUSTRY UTILITIES & 2562 & 0 & 1 & .06 & .23 \\
\hline
\end{tabular}

* Years 2006-2011 in total

BOARD ATTENDANCE $+b_{7}$ CSR INDEX $+b_{8}$ ESG DISCLOSURE $+b_{9}$ FINANCIAL PERFORMANCE + $\mathrm{b}_{10}$ FIRM SIZE $+\mathrm{b}_{11}$ LAW COMMON $+\mathrm{b}_{12}$ INDUSTRY BASIC MATERIALS + e

We used random effects estimations because our panel is unbalanced and we do not have important within-panel variations over time, which would otherwise require fixed effects estimations to give efficient estimates (Zhou, 2001). Note that the board characteristic variables, including board age and CEO duality, were stable for each company from one year to the next. In the following section, we present the empirical results of the univariate analyses, correlations, and binary logistic regression analyses.

\section{RESULTS}

\section{A. Univariate analyses}

We carried out univariate analyses to determine whether companies with a CSR committee within their BOD have an effective board, high corporate global performance, and high contextual sensitivity to CSR. It can be seen from Table 4 that, with respect to the board variables, companies with a CSR committee within their BOD had a higher average board age $(t=-3.91$, $\mathrm{p}<.001$ ), were more likely to have a CEO who is also 
Table 4: Univariate Analysis Results of T-tests Used to Compare the Means

\begin{tabular}{|c|c|c|c|}
\hline & $\begin{array}{c}\text { Absence of a CSR } \\
\text { Committee } \\
\text { within the BOD }\end{array}$ & $\begin{array}{c}\text { Presence of a CSR } \\
\text { Committee } \\
\text { within the BOD }\end{array}$ & \\
\hline Variable & Mean & Mean & T-Stat \\
\hline BOARD AGE & 57.35 & 58.38 & $-3.91 * * *$ \\
\hline BOARD INDEPENDENCE & 58.69 & 57.98 & .72 \\
\hline CEO DUALITY & .12 & .22 & $-4.05^{* * *}$ \\
\hline BOARD WOMEN & 12.01 & 10.29 & $2.97^{* *}$ \\
\hline BOARD SIZE & 11.12 & 11.71 & $-2.82^{* *}$ \\
\hline BOARD MEETINGS & 8.53 & 8.82 & -1.33 \\
\hline BOARD ATTENDANCE & 93.44 & 93.46 & .06 \\
\hline CSR INDEX & .26 & .40 & $-5.25^{* * *}$ \\
\hline ESG DISCLOSURE & 32.05 & 39.23 & $-7.09 * * *$ \\
\hline FINANCIAL PERFORMANCE & 19.72 & 20.84 & -.85 \\
\hline FIRM SIZE & 3.77 & 4.12 & $-9.36^{* * *}$ \\
\hline COMMON LAW & .29 & .59 & $-10.66^{* * *}$ \\
\hline INDUSTRY BASIC MATERIALS & .10 & .22 & $-5.21 * * *$ \\
\hline
\end{tabular}

$+\mathrm{p}<.10,{ }^{*} \mathrm{p}<.05,{ }^{* *} \mathrm{p}<.01,{ }^{* * *} \mathrm{p}<.001$

chair of the board $(t=-4.05, p<.001)$, had fewer women on the board $(\mathrm{t}=2.97, \mathrm{p}<.01)$, and had a larger board size $(\mathrm{t}=-2.82, \mathrm{p}<.01)$. The significant corporate global performance variables given in Table 4 show that companies with a CSR committee within their BOD had stronger corporate global performance: they were more likely to belong to a CSR index $(\mathrm{t}=-5.25$, $\mathrm{p}<.001)$ and to have a higher level of ESG disclosure $(\mathrm{t}=-7.09, \mathrm{p}<.001)$. With respect to the contextual sensitivity variables, we found that companies with a CSR committee within their BOD were more likely to be larger $(t=-9.36, p<.001)$, to have headquarters in common law countries $(\mathrm{t}=-10.66, \mathrm{p}<.001)$, and to be in the basic materials industry $(\mathrm{t}=-5.21, \mathrm{p}<.001)$. As discussed earlier, contextual sensitivity and global performance are likely to be high for companies with a CSR committee within their BOD. These univariate analyses may suggest that companies that have created a CSR committee are indeed inclined to achieve strategic changes for CSR and that they created them as tools to enhance CSR. But they may also be indicative of an explicit and symbolic response in the absence of hard laws or an implicit CSR tradition to a growing public concern about the impacts of large and highly profitable firms in resource-intensive sectors where both environmental and human risks are higher.

\section{B. Correlations}

Before testing our hypotheses using binary logistic regression analyses, we controlled for multi-collinearity. First, we tested all of the variables for normality using the STATA Skewness-Kurtosis test (sktest), and the variables were not found to be normally distributed. Therefore, we conducted a Spearman correlation test between the independent variables to minimize multi-collinearity a priori (see Table 5). Board size had a correlation coefficient higher than .5 (.58) with firm size. We decided to consider firm size instead of board size for our regression analysis for three reasons. First, the correlation coefficient of the presence of a CSR committee within the board was higher with firm size than with board size (respectively .18 and .08 in Table 5). Second, the T-test of means was more significant of firm size than of board size (respectively $\mathrm{p}<.001$ and $p<.01$ in Table 4). Third, we obtained the same results in regressions run with board size instead of firm size in terms of coefficient signs, while the variance explained with firm size was higher than with board size (Nagelkerke $\mathrm{R}^{2}$ higher).

The results of post-hoc tests for endogeneity with the variation inflation factor (VIF) are also summarized in Table 5. We found that all of the independent variables were below the suggested value of 10 ; the highest value 
Table 5: Spearman Correlation and Variance Inflation Factor (VIF) Tests

\begin{tabular}{|c|c|c|c|c|c|c|c|c|c|c|c|c|c|c|c|c|}
\hline & \multirow[b]{2}{*}{ VIF } & & & & & & & & & & & & & & \\
\hline & & & & 2 & 3 & 4 & 5 & 6 & 7 & 8 & 9 & 10 & 11 & 12 & 13 & 14 \\
\hline 1 & BOARD AGE & 1.33 & 1.00 & & & & & & & & & & & & & \\
\hline 2 & CEO DUALITY & 1.22 & .17 & 1.00 & & & & & & & & & & & & \\
\hline 3 & BOARD WOMEN & 1.22 & -.12 & .01 & 1.00 & & & & & & & & & & & \\
\hline 4 & BOARD INDEPENDENCE & 1.35 & .28 & -.06 & .22 & 1.00 & & & & & & & & & & \\
\hline 5 & BOARD SIZE & 2.06 & .05 & .23 & -.00 & -.27 & 1.00 & & & & & & & & & \\
\hline 6 & BOARD MEETINGS & 1.10 & -.12 & .01 & .11 & .04 & -.17 & 1.00 & & & & & & & & \\
\hline 7 & BOARD ATTENDANCE & 1.22 & -.09 & -.24 & .03 & .09 & -.31 & -.04 & 1.00 & & & & & & & \\
\hline 8 & CSR INDEX & 1.18 & .10 & .07 & .06 & .11 & .18 & .02 & -.06 & 1.00 & & & & & & \\
\hline 9 & ESG DISCLOSURE & 1.36 & .13 & .11 & .09 & .09 & .27 & .05 & -.07 & .31 & 1.00 & & & & & \\
\hline 10 & FINANCIAL PERFORMANCE & 1.07 & -.11 & -.06 & .02 & -.01 & -.14 & -.06 & .09 & .00 & -.08 & 1.00 & & & & \\
\hline 11 & FIRM SIZE & 2.46 & .29 & .20 & .10 & -.06 & .58 & .03 & -.25 & .39 & .47 & -.20 & 1.00 & & & \\
\hline 12 & COMMON LAW & 1.41 & -.24 & -.24 & -.10 & -.06 & -.22 & .09 & .28 & -.07 & -.11 & .10 & -.29 & 1.00 & & \\
\hline 13 & INDUSTRY BASIC MATERIALS & 1.03 & .09 & -.04 & -.06 & .10 & -.02 & -.09 & .04 & -.05 & .07 & -.08 & .03 & -.02 & 1.00 & \\
\hline 14 & CSR COMMITTEE & & .11 & .10 & -.04 & .00 & .08 & .05 & .01 & .11 & .15 & .02 & .18 & .22 & .13 & 1.00 \\
\hline
\end{tabular}

was 2.46 and the mean was 1.39 . Therefore, there were no multi-collinearity problems after the board size variable was excluded.

Correlation coefficients in bold are significant at $\mathrm{p}<$ .05 (2-tailed).

The regression model for the VIF test using ordinary least squares is CSR COMMITTEE $=\mathrm{f}$ (all independent variables 1-13 listed above).

\section{Binary logistic regression analyses}

We sought to identify the determinants of the presence of a CSR committee within a BOD by applying four logistic regression models, the results of which are shown in Table 6. Model 1 contained all of the independent variables of interest, whereas Model 4 was more parsimonious, using the variables that were significantly associated with the presence of a CSR committee at $\mathrm{p}<.10$. Model 3 was a baseline model comprising only the context-specific CSR sensitivity variables. It can be seen that adding board variables to Model 3, forming Model 2, significantly improved the Nagelkerke $\mathrm{R}^{2}$, from .23 to .36 . Then, Model 1 shows how the corporate global performance variables contributed to improve again the model, changing $\mathrm{R}^{2}$ from .36 (Model 2) to .40 (Model 1), a much smaller improvement than that obtained by adding board related variables.

Odds ratios $\operatorname{Exp}(\mathrm{B})$ higher than 1.10 or lower than 0.90 were considered functionally or practically significant contributions. Using this criterion, Table 6 shows the following. First, concerning the board, a BOD with a CSR committee is 3.98-4.37 times more likely to have CEO duality. But BODs having created a CSR committee do not show characteristics such as youth and diversity generally associated with CSR. Second, concerning corporate global performance, firms with a CSR committee within the BOD are 1.73-1.99 times more likely to belong to a CSR index. Finally, concerning contextual sensitivity, a BOD with a CSR committee is 4.35-6.08 times more likely to be in larger firms, 7.51-17.62 times more likely to be in firms that have headquarters in common law countries, and 3.20-5.88 times more likely to be in firms within the basic materials industry than a BOD without a CSR committee. Thus, a CSR committee is more likely to be created in firms with a high contextual sensitivity. Tables 7 and 8 summarize the findings in relation to the hypotheses. We found that, with respect to the three hypotheses on board process effectiveness, composition and structure (Table 7), only board duality made a non-trivial difference. Of the hypotheses on corporate global performance (Table 8), belonging to a CSR index made a non-trivial difference, confirming that companies with a CSR committee within their BOD did indeed engage in CSR. Also, the three hypotheses on contextual sensitivity were all supported, demonstrating that a CSR committee within the BOD is likely to be present in high contextual sensitivity companies. It is worth noting that some variables had a much more stronger regression weights than others, which might be of importance to understand why CSR committees are created. The first variable, well ahead of the others, is the common law jurisdiction (7.51-17.62). Secondly, firm size (4.35-6.08) and industry (3.20-5.88) seems equally important to CEO duality (3.98-4.37). All other variables show a regression odds ratio below 2 . This points to the fact that contextual sensitivity factors remain the more important despite the improvement of the Nagelkerke $\mathrm{R}^{2}$ shown by the Model 2 that integrates board variables; indeed, amongst those latter variables, only CEO duality seems to be decisive. 
Table 6: Binary Logistic Regression Results

\begin{tabular}{|c|c|c|c|c|c|c|c|c|}
\hline \multirow[t]{3}{*}{ Variable } & \multicolumn{2}{|c|}{ Model 1} & \multicolumn{2}{|c|}{ Model 2} & \multicolumn{2}{|c|}{ Model 3} & \multicolumn{2}{|c|}{ Model 4} \\
\hline & \multicolumn{2}{|c|}{ CSR COMMITTEE } & \multicolumn{2}{|c|}{ CSR COMMITTEE } & \multicolumn{2}{|c|}{ CSR COMMITTEE } & \multicolumn{2}{|c|}{ CSR COMMITTEE } \\
\hline & B & $\operatorname{Exp}(B)$ & B & $\operatorname{Exp}(B)$ & B & $\operatorname{Exp}(B)$ & B & $\operatorname{Exp}(B)$ \\
\hline BOARD AGE & $.08^{*}$ & 1.09 & $.08^{*}$ & 1.09 & & & $.07^{*}$ & 1.07 \\
\hline BOARD INDEPENDENCE & $-.02^{* *}$ & .98 & $-.02^{* *}$ & .98 & & & $-.02 * * *$ & .98 \\
\hline CEO DUALITY & $1.47^{* * *}$ & 4.37 & $1.40^{* * *}$ & 4.06 & & & $1.38^{* * *}$ & 3.98 \\
\hline BOARD WOMEN & $-.02+$ & .98 & -.01 & .99 & & & $-.03^{* *}$ & .97 \\
\hline BOARD MEETINGS & $.08^{* *}$ & 1.09 & $.07^{*}$ & 1.07 & & & & \\
\hline BOARD ATTENDANCE & -.02 & .98 & -.01 & .99 & & & & \\
\hline FINANCIAL PERFORMANCE & $.02^{* * *}$ & 1.02 & & & & & $.01^{* *}$ & 1.01 \\
\hline CSR INDEX & $.69^{* *}$ & 1.99 & & & & & $.55^{* *}$ & 1.73 \\
\hline ESG DISCOSURE & .01 & 1.01 & & & & & $.01 *$ & 1.01 \\
\hline FIRM SIZE & $1.76^{* * *}$ & 5.82 & $1.80^{* * *}$ & 6.08 & $1.47^{* * *}$ & 4.35 & $1.55^{* * *}$ & 4.64 \\
\hline LAW COMMON & $2.87^{* * *}$ & 17.62 & $2.81^{* * *}$ & 16.65 & $2.02^{* * *}$ & 7.51 & $2.36^{* * *}$ & 10.62 \\
\hline INDUSTRY BASIC MATERIALS & $1.77^{* * *}$ & 5.88 & $1.67^{* * *}$ & 5.33 & $1.16^{* * *}$ & 3.20 & $1.41^{* * *}$ & 4.09 \\
\hline Constant & $-13.87^{* * *}$ & .00 & $-14.09 * * *$ & .00 & $-8.74^{* * *}$ & .00 & $-12.79 * * *$ & .00 \\
\hline Sample size & \multicolumn{2}{|c|}{1152} & \multicolumn{2}{|c|}{1198} & \multicolumn{2}{|c|}{2537} & \multicolumn{2}{|l|}{1395} \\
\hline Number of variables & \multicolumn{2}{|c|}{12} & \multicolumn{2}{|c|}{9} & \multicolumn{2}{|c|}{3} & \multicolumn{2}{|c|}{9} \\
\hline - 2 Log Likelihood & \multicolumn{2}{|c|}{730.92} & \multicolumn{2}{|c|}{785.49} & \multicolumn{2}{|c|}{1635.71} & \multicolumn{2}{|c|}{905.36} \\
\hline Nagelkerke $\mathrm{R}^{2}$ & \multicolumn{2}{|c|}{.40} & \multicolumn{2}{|c|}{.36} & \multicolumn{2}{|c|}{.23} & \multicolumn{2}{|c|}{.36} \\
\hline
\end{tabular}

$+\mathrm{p}<.10,{ }^{*} \mathrm{p}<.05,{ }^{* *} \mathrm{p}<.01,{ }^{* * *} \mathrm{p}<.001$

The estimated equation using binary logistic regressions is CSR COMMITTEE $=\mathrm{f}($ all independent variables listed above $)$.

Table 7: Board Power to Enhance CSR Hypotheses Verification

\begin{tabular}{|c|c|c|}
\hline $\begin{array}{l}\text { Hypothesis } \\
\text { number }\end{array}$ & Hypothesis & Result \\
\hline & $\begin{array}{l}\text { There is more likely to be a CSR committee within the board in companies ... } \\
\text {....with higher board use of social knowledge and skills, therefore: }\end{array}$ & \\
\hline $1 \mathrm{a}$ & having younger board directors. & Rejected \\
\hline $1 b$ & $\begin{array}{l}\text { with a higher proportion of independent directors on the board. } \\
\text {...with higher board cognitive conflict, therefore: }\end{array}$ & Rejected \\
\hline $2 \mathrm{a}$ & where the chief executive officer is not also the chair of the board. & Rejected \\
\hline $2 b$ & $\begin{array}{l}\text { with a higher proportion of women on the board. } \\
\text {...with higher board effort, therefore: }\end{array}$ & Rejected \\
\hline $3 a$ & with more board meetings. & Inconclusive \\
\hline $3 b$ & with higher board attendance. & Inconclusive \\
\hline
\end{tabular}

Table 8: Board Inclination for CSR Hypotheses Verification

\begin{tabular}{|clr|}
\hline $\begin{array}{c}\text { Hypothesis } \\
\text { number }\end{array}$ & \multicolumn{1}{c|}{ Hypothesis } & Result \\
\hline & There is more likely to be a CSR committee within the board in companies ... & Supported \\
& ... with higher corporate social performance, therefore: & Inconclusive \\
$4 \mathrm{a}$ & belonging to a CSR index. & Inconclusive \\
$4 \mathrm{~b}$ & with stronger environmental, social and governance disclosure. & Supported \\
& with stronger financial performance. & Supported \\
$5 \mathrm{a}$ & ... with higher context-specific CSR sensitivity, therefore: & Supported \\
$5 \mathrm{~b}$ & with larger firm size. & having headquarters in common law countries.
\end{tabular}




\section{DISCUSSION}

Our findings have theoretical and practical implications that we present below. Our study brings a number of nuances into the often taken-for-granted positive link between firms' governance attributes and quality, on one hand, and their CSR performance and engagement, on the other. It provides empirical support to the earlier claim about the necessity of adopting sound governance structures to achieve strategic CSR. However, our empirical investigation results seem to imply that the presence of a CSR committee at the board level is a choice among others, mostly explained by:

- variety of capitalism: higher occurrence in common-law countries;

- strategic choice (agency-viewpoint and needs for legitimacy): more present in large, highly profitable firms, displaying CEO duality, and operating in resource-intensive sectors, and;

- resource-based logics: more frequent in large firms and less frequent in smaller ones and in those which have already chosen to adopt other governance "best-practices" such as gender-diversity, youthening, independence-enhancement of the BOD.

Although prior studies have demonstrated that CSR committees are likely to be created to achieve better corporate social performance by companies already showing good CSR performance, most of them were focused on only one set of factors (for example, the BOD's composition or structure or functioning) overlooking the others and their possible offsetting with each other in contexts of varying national business systems, strategic choice, and resource-scarcity.

First of all, not surprisingly, our study demonstrates that the common law jurisdiction is the most important variable explaining the presence of a CSR committee. Firm size and the industry favour CSR committee, but the most important factor remains the jurisdiction, companies operating in common law countries being more likely to have a distinct CSR committee in the board than companies operating in civil law countries. Coupled with firm size and industry, the jurisdiction weight in the regression results confirms the predominance of contextual sensitivity in explaining this feature of boards. As Matten and Moon (2004) hypothesized, common-law countries generally belong to liberal-market economies where non-mandatory explicit CSR practices are more likely to be found. The creation of CSR committees within the BOD is an example of such a practice. In UK and other Liberal-market economies countries, despite the advent of governance reforms and hence that of codes, rules and guidelines from the beginning of 2000s, CSR-function-specialisation at the board level has not become regulated. Our study also corroborates the findings of earlier ones such as that of Igalens et al. (2008) which showed that Liberal-market economies-bound companies are more likely to adopt corporate governance "best practices" and score higher on governance dimensions, comparatively to companies in other contexts (European continental, Social-democrat, and Mediterranean).

Second, our findings back assumptions from the agency and legitimacy perspectives on corporate strategic choice. We found that CEO duality fosters CSR committees. Although that contradicts the findings of past studies which linked CEO duality negatively with CSR performance (for example, Webb, 2004; Mallin and Michelon, 2011), that is consistent with an agency-theoritical logics. Powerful CEOs, holding dual functions, might favour other governance practices to counterbalance suspicions arising from their lack of independence, thus signalling to shareholders their trustworthiness. A similar conclusion was reached by Jizi et al. (2014) in their study of the positive link between CEO duality and voluntary disclosure in the US banking sector. They suggest among other possible explanations: private reputational concerns, managerial risk aversion, and the pressure to appease stakeholders' concerns about probable power abuse. In addition to CEO duality, our study found financial performance, size and sector sensitivity as determinants of the presence of a CSR committee within the BOD. It can be implied from those findings that companies choosing to adopt such a practice do so strategically, follow a pragmatic legitimacy logic. That seems even more predictable in Liberal-market economies or common-law countries where explicit and symbolic response is more frequent in the absence of hard laws or an implicit CSR tradition to a growing public concern about the impacts of large and highly profitable firms in resource-intensive sector where both environmental and human risks are higher. That is also consistent with the fact that to a lesser extent, inclusion in a CSR index is linked to the presence of a CSR committee, as our results imply. This variable may be a proxy for governance efforts, as suggested by its high correlations with firm size and ESG reporting. And we found that it cannot be reduced to circularity given their correlation coefficient.

Third and lastly, we found that with the notable exception of CEO duality, the board structure, composition and functioning are barely correlated to the presence of a CSR committee. This may seem surprising given the opposite claims from earlier studies which linked positively BOD's diversification (in age and gender) and functioning (number of meeting and attendance) with CSR performance. However, our results suggest that such conclusions must be handled with caution. Regarding the average age of the board, even if there is a correlation between this variable and the presence of a CSR committee, the difference is only one year: directors in board having a CSR committee are 58,38 years old whereas directors in board not having such committee are 57,35 years old. The group differences for independent and women directors on the board were also very small. But most importantly - and here lies another contribution of our study -, the fact 
that the structure and composition of the board does not seem to have a real significant impact on the presence of CSR committees can be understood from a resource-based logic. When used to explain corporate social strategy, the resource-based approach allows an understanding of the adoption of CSR activities as the result of a resource-allocation's choice which would help the company to achieve long-term social objectives while creating a competitive advantage (Bowen, 2007). In a context of resource scarcity, a company will thus choose some practices over some others. Moreover, it will not invest in practices the objectives of which are already met by existing ones. Such assumptions were absent from prior studies about the link between BOD's attributes and the presence of a CSR committee (for example, Menon \& Williams, 1994; Fiss \& Zajac, 2004). In light of our results, it could be argued that to the extent that the presence of a CSR committee is a reflection of corporate social strategy, especially in a context of resource scarcity, it occurs less in companies which have already developed their BOD's cognitive competencies through gender-diversification, youthening, and independence.

\section{CONCLUSION}

In this exploratory study, our goal was to understand the factors influencing the presence of a CSR committee. Our results confirm the conclusion of Eccles, Ioannou \& Serafeim (2011) and of Danvila del Valle and al. (2013) that CSR committees are created in companies already showing a good social performance as reflected by inclusion in a CSR index. However, our results do not confirm other studies about the effect of younger, independent or women directors on board engagement towards CSR. Given that CEO duality does have a significant effect on the presence of a CSR committee, our research seems to confirm the difference of view between CEO directors and CEO non directors showed by Wang \& Dewhirst (1992). But contrary to Webb (2014), we found that CEO duality goes hand in hand with the presence of a CSR committee.

We found that different elements were determinants of the presence of a CSR committee within a BOD. The more important factor is the jurisdiction in which the company operates: in common law countries, CSR committees are more likely to be created than in civil law jurisdictions. Moreover, it seems that companies having a CEO that is also chair of the board tend to create those committees more than companies where those responsibilities are separated. This last factor is as important as firm size or the industry to which the company belongs.

If they contradict or do not corroborate some former analysis, the findings from our study are indeed consistent with combined assumptions from the variety of capitalism, strategic choice (agency and legitimacy), and resource-based perspectives. Hence, our study contributes to the non-stabilized literature on the link between CSR and governance by nuancing prior hypotheses and findings about the determinants of the presence of a CSR committee within a BOD.

It is hoped that the results of this cross-cultural study will contribute to understanding the choices of CSR governance structures among practitioners and policy makers. A CSR committee within a BOD can play an important role by continually prioritizing CSR problems, identifying solutions and regularly reporting to the board of directors. It thus represents a response to Porter $\&$ Kramer's (2006: 92) suggestion that firms concentrate their efforts on identifying "the particular set of societal problems that it is best equipped to help resolve and from which it can gain the greatest competitive benefit". The way in which a company describes itself in annual reports and CSR reports, from which Bloomberg also gathers data, does not necessarily correspond with its real practices. Therefore, to further investigate this area, we suggest that qualitative studies, such as content analyses, case studies, or questionnaires directed at board directors be conducted. These studies could also help determine whether the sample companies are at the stage of only implementing CSR or at a more advanced stage, that is monitoring CSR.

We also suggest that further empirical studies could be conducted to determine which characteristics of the CSR committee within the BOD influence social, environmental, and economic performance. The results of such research could be of benefit to companies that intend to create a CSR committee within their BOD as a useful and efficient structure to achieve CSR.

Based on our findings, it could also be interesting to conduct two new studies. The first one would investigate the creation and development of CSR committees starting from 2011, which is the end of our sample, and see if there is an evolution in the factors explaining the existence and the persistence of those committees over time. The second one would be to conduct a comparative study between common law and civil law countries to understand the interest of such distinct committees in boards of directors. Further studies might also be conducted to monitor the effect of independent, women and younger directors on CSR decisions and the governance structure of a company. Also, by undertaking a longitudinal study, we could analyse if creating a CSR committee within a BOD is a first step for a company or if it is the result of a mature strategy towards CSR issues. Finally, more inquiries should be undertaken as regards to the actual engagement versus the symbolic implication of the availability of a CSR committee. More specifically, we suggest that be explored the process through which a BOD which displays a highly diverse composition (gender and age), a high rate of independent directors, and which has adopted better functioning can achieve CSR performance even in the absence of a CSR committee. It will also be relevant to investigate in which institutional settings (national business systems, types of 
capitalism) the existence of such a committee is likely to entail a real engagement to CSR issues from the board versus a merely symbolic practice.

\section{ACKNOWLEDGEMENTS}

The authors are grateful to RobecoSAM in Zurich for providing pertinent data. This research received a grant from the Lorraine Region in France.

\section{BIBLIOGRAPHY}

Aguilera, R.V., Rupp, D.E, Williams, C.A. \& Ganapathi, J. 2007. Putting the $S$ back in corporate social responsibility: a multilevel theory of social change in organizations. Academy of Management Review, 32(3): 836-863.

Allouche, J. \& Laroche, P. 2005. A meta-analytical examination of the link between corporate social and financial performance. Revue de Gestion des Ressources Humaines, 57: 18-41.

Aoki, M. 2000. Information and governance in the Silicon Valley model. In: Xavier Vives (Ed.), Corporate governance: theoretical \& empirical perspectives: 169-195, Cambridge: Cambridge University Press.

Artiach, T., Lee, D.D., Nelson, D. \& Walker, J.K. 2010. The determinants of corporate sustainability performance. Accounting \& Finance, 50(1): 31-51.

Barroso-Castro, C., Villegas-Perinan, M.M., \& Dominguez, M. 2017. Board members' contribution to strategy: The mediating role of board internal processes, European Research on Management and Business Economics, 23(2): 82-89.

Bear, S., Rahman, N. \& Post, C. 2010. The impact of board diversity and gender composition on corporate social responsibility and firm reputation. Journal of Business Ethics, 97: 207-221.

Beltratti, A. 2005. The complementarity between corporate governance and corporate social responsibility. The Geneva Papers, 30: 373-386.

Boulouta I. 2013. Hidden Connections: The link between board gender diversity and corporate social performance. Journal of Business Ethics, 113: 185-197.

Bowen, F. 2007. Corporate social strategy: competing views from two theories of the firm, Journal of Business Ethics, 75: 97-113.

Brauer, M. \& Schmidt, S. 2008. Defining the strategic role of boards and measuring boards' effectiveness in strategy implementation, Corporate Governance, 8(5): 649-660.

Brennan, N. \& Solomon, J. 2008. Corporate governance, accountability and mechanisms of accountability: an overview, $\boldsymbol{A c}$ counting, Auditing \& Accountability Journal, 21(7): 885-906.

Caron, M.-A. \& Gendron, C. 2012. Faire entrer la responsabilité sociale de l'entreprise en démocratie, Revue de l'Organisation Responsable, 7(1): 5-17.

Cartwright, W.\& Craig, J. 2006. Sustainability: aligning corporate governance, strategy and operations with the planet, Business Process Management Journal. 12(6): 741-750.

Cicon, J.E., Ferris, S.P., Kammel, A.J. \& Noronha, G. 2012 European corporate governance: a thematic analysis of national codes of governance. European Financial Management, 18(4): 620-648.
Cornforth, C. 2001. What Makes Boards Effective? An examination of the relationships between board inputs, structures, processes and effectiveness in non-profit organisations. Corporate Governance: an International Review, 9(3): 217-227.

Danvila del Valle, I., Diez Esteban, J.M. \& Lopez de Foronda, O. 2013. Corporate social responsibility and sustainability committee inside the board. (Working paper SSRN no. 2260382). Burgos: University of Burgos.

Davis, G.F., Whitman, M.V.N. \& Zald, M.N. 2006. The responsibility paradox: multinational firms and social corporate social responsibility. (Working paper no. 1031). Ann Arbor, MI: Ross School of Business.

Diamantopoulos, A., Schlegelmilch, B.B., Sinkovics, R.R. \& Bohlen, G.M. 2003. Can socio-demographics still play a role in profiling green consumers? A review of the evidence and an empirical investigation. Journal of Business Research, 56: 465-480.

Donaldson, T. \& Preston, L. 1995. The stakeholder theory of the Corporation: concepts, evidence, and implications. The Academy of Management Review, 20(1): 65-91.

Eccles, R.G., Ioannou, I. \& Serafeim, G. 2011. The impact of a corporate culture of sustainability on corporate behavior and performance. (Working paper SSRN no. 1964011), Cambridge, MA: Harvard Business School.

Elkington, J. 1998. Cannibals with forks: The triple bottom line of 21st century business. Gabriola Island, BC: New Society Publishers.

Elkington, J. 2006. Governance for sustainability. Corporate Governance: an International Review, 14(6): 522-529.

European Commission. 2001. Green Paper: Promoting a European framework for Corporate Social Responsibility. Bruxelles: European Commission.

European Commission. 2011. A renewed EU strategy 201114 for Corporate Social Responsibility. Bruxelles: European Commission.

Fiss, P.C. \& Zajac E.J. 2004. The diffusion of ideas over contested terrain: the (non)adoption of a shareholder value orientation among German firms. Administrative Science Quarterly, 49: 501-534.

Forbes, D.P. \& Milliken, F.J. 1999. Cognition and corporate governance: Understanding boards of directors as strategic decision-making groups. Academy of Management Review, 24(3): 489-505.

Financial Times Stock Exchange. 2012. Industry Classification Benchmark. London: FTSE International Limited. Available at: http://www.icbenchmark.com/ICBDocs/Structure_Defs_English.pdf

Fuentel, J.A., Garcia-Sanchez, M., \& Lozano, M.B. 2017. The role of the board of directors in the adoption of GRI guidelines for the disclosure of CSR information, Journal of Cleaner Production, 141(10), 737-750.

Galbreath, J. 2018. Is Board Gender Diversity Linked to Financial Performance? The Mediating Mechanism of CSR, Business \& Society, 57(5) : 863-889.

Gendron C. 2012. Ecological Modernisation and Business Leaders. Regulation Theory and Sustainable Development, Londres : Routledge, 224 p.

Golden, B.R. \& Zajac E.J. 2001. When will boards influence strategy? Inclination $\times$ power $=$ strategic change. Strategic Management Journal, 22: 1087-1111.

Harjoto, M.A. \& Jo, H. Corporate governance and CSR nexus, Journal of Business Ethics, 100(1): 45-67. 
Harrison, J.R. 1987. The strategic use of board committees. California Management Review, 30(1): 109-125.

Hoepner, A.G.F., Yu, P.S. \& Ferguson J. 2010. Corporate social responsibility across industries: When can who do well by doing good? (Working paper SSRN no. 1284703). Saint Andrews: University of Saint Andrews School of Management.

Horner, S.V. 2011. Board Power and Corporate Strategic Focus: A Model of Board Impact on Firm Strategy. Journal of Leadership, Accountability, and Ethics, 8(4): 26-41.

Hung, H. 2011. Directors' roles in corporate social responsibility: a stakeholder perspective. Journal of Business Ethics, 103: 385-402.

Igalens, J., Déjean, F. \& Akremi, A.E. 2008. L’influence des systèmes économiques sur la notation sociétale. Revue française de gestion, 34(183): 135-155.

Ioannou, I. \& Serafeim, G. 2011. The consequences of mandatory corporate sustainability reporting. (Working paper SSRN no. 1799589). London: London Business School and Cambridge, MA: Harvard Business School.

International Organization for Standardization. 2010. ISO 26000:2010 —Guidance on social responsibility. http:// www. iso.org/iso/catalogue_detail?csnumber $=42546$.

Jizi, M.I, Salama, A., Dixon, R., \& Stratling, R. 2014. Corporate Governance and Corporate Social Responsibility Disclosure: Evidence from the US Banking Sector, Journal of Business Ethics, 125(4): 601-615.

Kinderman, D.P. 2013. Corporate social responsibility in the EU, 1993-2013: Institutional ambiguity, economic crises, business legitimacy, and bureaucratic politics. Journal of Common Market Studies, 51(4): 701-720.

La Porta, R., Lopez-de-Silanes, F., Shleifer, A. \& Vishny, R.W. 1998. Law and finance. Journal of Political Economy, 107(6): 1113-1155.

La Porta, R., Lopez-de-Silanes, F. \& Shleifer, A. 2008. The economic consequences of legal origins. Journal of Economic Literature, 46(2): 285-332.

Luoma, P. \& Goodstein, J. 1999. Stakeholders and corporate boards: institutional influences on board composition and structure. Academy of Management Journal, 42(5): 553-563. McGuinness, P.B., Vieito, J.P., \& Wang, M. 2017. The role of board gender and foreign ownership in the CSR performance of Chinese listed firms Journal of Corporate Finance, 42: 75-99.

Mallin, C., Michelon, G. \& Raggi, D. 2013. Monitoring intensity and stakeholders' orientation: how does governance affect social and environmental disclosure? Journal of Business Ethics, 114: 29-43.

Mallin, C. \& Michelon, G. 2011. Board reputation attributes and corporate social performance: an empirical investigation of the US best corporate citizens. Accounting and Business Research, 41(2): 119-144.

Matten, D. \& Moon, J. 2008. "Implicit" and "explicit" CSR: a conceptual framework for a comparative understanding of corporate social responsibility. Academy of Management Review, 33(2): 404-424.

Menon, K. \& Williams, J.D. 1994. The use of audit committees for monitoring. Journal of Accounting and Public Policy, 13: 121-139.

Muller-Kahle, M.I. \& Lewellyn, K.B. 2011. Did board configuration matter? The case of US subprime lenders. Corporate Governance: An International Review, 19(5): 405-417.

Nelson, J., Zollinger, P. \& Singh, A. 2001. The power to change: Mobilising board leadership to deliver sustainable value to markets and society. London: The International Business Leaders Forum and SustainAbility.

Ntim, C.G. \& Soobaroyen T. 2013. Corporate governance and performance in socially responsible corporations: New empirical insights from a neo-institutional framework. Corporate Governance: An International Review, 21(5): 468-494.

Orlitzky, M., Schmidt, F. L. \& Rynes S.L. 2003. Corporate social and financial performance: a meta-analysis. Organization Studies, 24(3): 403-441.

Perrault, E., \& McHugh, P. 2015. Toward a life cycle theory of board evolution: Considering firm legitimacy. Journal of Management and Organization, 21(5): 627-649.

Porter, M.E. \& Kramer, M.R. 2006. Strategy \& Society: The link between competitive advantage and corporate social responsibility. Harvard Business Review, 84(12): 78-92.

Post, C., Rahman, N. \& Rubow, E. 2011. Green governance: boards of directors composition and environmental corporate social responsibility. Business \& Society, 50(1): 189-223.

Pugliese, A., Bezemer, P.-J., Zattoni, A., Huse, M., Van den Bosch, F.A.J., \& Volberda, H.W. 2009. Boards of directors' contribution to strategy: a literature review and research agenda. Corporate Governance: an International Review, 17(3): 292-306.

Qi, L. 2018. How do Female Leadership Traits Affect Corporate Social Responsibility Performance in China. China-Canada Forum on Science \& Technology Innovation and Entrepreneurchip Policy, UQAM Montreal, 6-7 august 2018

Raghunandan, K.. \& Rama, V.D. 2007. Determinants of audit committee diligence. Accounting Horizons, 21(3): 265-279.

Rao, K., \& Tilt, C. 2016. Board Composition and Corporate Social Responsibility: The Role of Diversity, Gender, Strategy and Decision Making, Journal of Business Ethics, 138(2): 327-347. Rindova. V.P. 1999. What corporate boards have to do with strategy: a cognitive perspective. Journal of Management Studies, 36(7): 953-975.

Rodrigue, M., Magnan, \& Cho, C.H. 2013 Is environmental governance substantive or symbolic? An empirical investigation. Journal of Business Ethics, 114: 107-129.

SAM, 2012. Measuring intangibles. SAM's corporate sustainability assessment methodology. Zurich: Sustainability Asset Management.

Schwartz-Ziv, M. 2013. Does the gender of directors matter? (Edmond J. Safra working papers no. 8). Cambridge, MA: Harvard University.

Shaukat, A., Qiu, Y, \& Trojanowski, G. 2016. Board Attributes, Corporate Social Responsibility Strategy, and Corporate Environmental and Social Performance, Journal Business Ethics, 135(3): 569-585.

Spira, L.F. \& Bender, R. 2004. Compare and contrast: perspectives on board committees. Corporate Governance: an International Review, 12(4): 489-499.

Tencati, A. \& Zsolnai, L. 2009. The collaborative enterprise. Journal of Business Ethics, 85: 367-376.

Tonello, M. 2010, Sustainability in the boardroom. New York: The Conference Board Director Notes no. DN-008.

Tonello, M., Vidal, D.J., Carroll, A.B., Shabana, K.M., Kerr, J.E., Peloza, J., Shang, J., Lemon, K.N., Roberts, J.H., Raghubir, P., Winer, R., Du, S., Bhattacharya, C.B., Sen, S., Lev, B.I., Petrovits, C. \& Radhakrishnan, S. 2011. Sustainability matters: Why and how corporate boards should become involved. (Research Report no. R-1481-11-R). New York: The Conference Board. Udayasankar, K. 2008. Corporate social responsibility and firm size. Journal of Business Ethics, 83: 167-175. 
UNEP. 2011. Towards a Green Economy: Pathways to Sustainable Development and Poverty Eradication. 626 p.

United Nations Principles for Responsible Investment (UN PRI). 2006. ESG Issues - Social issues. https://www.unpri. org/esg-issues/social-issues

Waddock, S.A., \& Graves, S.B. 1997. The corporate social performance-financial performance link. Strategic Management Journal, 18(4): 303-319.

Wang, J. \& Dewhirst, H.D. 1992. Boards of directors and stakeholder orientation. Journal of Business Ethics, 11: 115-123.

Webb, E. 2004. An examination of socially responsible firms' board structure. Journal of Management and Governance, 8: 255-277.

Wiersema, M.F. \& Bantel, K.A. 1992. Top management team demography and corporate strategic change. Academy of $\mathbf{M a}$ nagement Journal, 35(1): 91-121.
World Business Council for Sustainable Development. (1999). Corporate social responsibility: Meeting changing expectations. Geneva: WBCSD.

World Commission on Environment and Development. (1987). Our common future. World commission on environment and development. Oxford: Oxford University Press.

Wu, Q., He, Q., Duan, Y. \& O'Regan, N. 2012. Implementing dynamic capabilities for corporate strategic change toward sustainability. Strategic Change, 21: 231-247.

Zhang, J.Q., Zhu,H. \& Ding, H-B. 2013. Board composition and corporate social responsibility: an empirical investigation in the post Sarbanes-Oxley era. Journal of Business Ethics, 114(3): 381-392.

Zhou, X. 2001. Understanding the determinants of managerial ownership and the link between ownership and performance: comment. Journal of Financial Economics, 62(3): 559-571. 